\title{
PREGNANCY ASSOCIATED GLYCOPROTEINS IN RUMINANTS: INACTIVE MEMBERS OF THE ASPARTIC PROTEINASE FAMILY*
}

\author{
J. F. BECKERS ${ }^{1}$, P. V. DRION ${ }^{1}$, J. M. GARBAYO ${ }^{1}$, ZS. PERÉNYI ${ }^{2}$, A. ZARROUK ${ }^{1}$, \\ J. SULON ${ }^{1}$, B. REMY ${ }^{1}$ and O. SZENCI ${ }^{2 * *}$ \\ ${ }^{1}$ University of Liege, Faculty of Veterinary Medicine, Physiology of Reproduction, \\ Bd de Colonster 20 B41, B-4000 Sart-Tilman, Belgium; ${ }^{2}$ University of Veterinary \\ Science, Department of Obstetrics and Reproduction, H-1400 Budapest, P.O. Box 2, \\ Hungary
}

(Received January 25, 1999; accepted March 8, 1999)

The Pregnancy Associated Glycoproteins (PAGs) presented in this paper are largely expressed in the ruminant placenta. These proteins are classified as probably inactive members of the aspartic proteinase family. Pepsinogen, renin, cathepsin E \& $\mathrm{D}$ and chymosine are typical members of this family, characterised by the presence of aspartic acids boarding the recognition sites. Secreted in the peripheral blood of the pregnant female from early pregnancy, these proteins can be used in serological tests for establishing different diagnoses. In the veterinary practice, these diagnoses are useful for both pregnancy confirmation and follow-up of trophoblastic function. The first aspect can help breeders in the management of reproduction, while the second one more specifically concerns clinicians and researchers wishing to establish a differential diagnosis of pathologic conditions affecting pregnancy.

Key words: Pregnancy associated glycoproteins, cow, sheep, goat

\section{Pregnancy associated glycoproteins of ruminants}

Proteins secreted by the placenta (Beckers et al., 1998), when detected in the peripheral circulation of the mother, can be useful indicators of both pregnancy and feto-trophoblast well-being (Aschheim and Zondek, 1928; Sciarra et al., 1963; Bohn, 1979). In 1982, Butler et al. isolated two pregnancy-specific proteins (PSPA and PSPB) from bovine placental membranes. PSPA was identified as $\alpha-$ fetoprotein which is not strictly limited to pregnancy, while PSPB was confirmed as being specific for the placenta and pregnancy (Sasser et al., 1986). PSPB was

\footnotetext{
*This paper was published in the proceedings of the Xth Congress of the Hungarian Association for Buiatrics (Siófok, May 21-23, 1998)

${ }^{* *}$ Corresponding author; E-mail: oszenci@ns.univet.hu
} 
characterised as a glycoprotein showing relative molecular masses $(\mathrm{Mr})$ between 47 and $53 \mathrm{kDa}$ and presenting different isoelectric points (from 4.0 to 4.4). The $\mathrm{Mr}$ of PSPB was similar to the Mr of the molecule isolated by Laster (1977).

In 1991, Zoli et al. purified a pregnancy-associated glycoprotein (PAG), later designated as PAG-1 (Xie et al., 1991, 1995) and currently designated as PAG-I-67 because its $\mathrm{Mr}$ is $67 \mathrm{kDa}$. Four isoforms (PI: 4.4, 4.6, 5.2 and 5.4) were detected in the initial preparation. Subsequent molecular cloning studies showed that PSPB and PAG-I-67 were closely related in primary structure (Lynch et al., 1992). These glycoproteins (either PSPB and PAG-I-67) could be detected in the maternal circulation at around the time when the trophoblast forms definitive attachment to the uterine wall. Afterwards their concentrations increase gradually and reach peak values of about 1 to $5 \mu \mathrm{g} / \mathrm{ml}$ just before parturition (Sasser et al., 1989; Zoli et al., 1992). PSPB and PAG molecules are routinely determined in peripheral maternal blood as pregnancy markers in cattle (Sasser et al., 1986; Humblot et al., 1988a; Zoli et al., 1992; Ectors et al., 1996; Szenci et al., 1998a,b).

Glycoproteins immunologically related to PAG-I-67 and PSPB have been isolated and partially characterised from ovine fetal cotyledons: oPAG, later designated as oPAG-I (Zoli et al., 1995) and oPSPB (Willard et al., 1995). They also have been detected in maternal blood by week 3 (Willard et al., 1995) or week 4 (Ranilla et al., 1994) after breeding. Different forms (differing in Mr and isoelectric point) were characterised after isolation from sheep cotyledons cultured in vitro (Xie et al., 1997). Very recently, three different PAGs having $\mathrm{Mr}$ of 55, 59 and $62 \mathrm{kDa}$ have been characterised from goat placenta. Each of them presented various isoelectric points (Garbayo et al., 1998).

In 1991, Xie et al. cloned PAG (now known as PAG-I-67) from late bovine and ovine placenta by screening cDNA libraries with two anti-PAG antisera. The bovine and ovine cDNAs encoding PAG-I shared $86 \%$ identity in nucleotide sequence encoding for proteins of 380 and 382 amino acids, respectively, including a 15 amino acid signal sequence. However, protein sequence data (peptide sequencing) have already shown that the first amino acid of the bovine PAG-I-67 is an arginine that corresponds to another one located at position 39. The downstream of the side of signal sequence cleavage indicates that PAG-I-67 undergoes post-translational modifications from a pro-form.

\section{PAGs: Members of the Aspartic Proteinase family}

The most surprising feature of PAG revealed by the cloning experiment on bovine and ovine molecules in 1991 (Xie et al., 1991) was that they belonged to a large family of proteolytic enzymes known as aspartic proteinases. In par- 
ticular, the PAGs [PAG-I (bovine) and PAG-I (ovine): $\mathrm{NH}_{2}$ terminus: FDTASS and FDTGSS; COOH terminus: VDTGTS and VGTGTS, respectively] had the greatest sequence identity with pepsinogens [Pepsin (human), Cathepsin D and E (human): $\mathrm{NH}_{2}$ terminus: FDTGSS; $\mathrm{COOH}$ terminus: VDTGTS, respectively] (Atkinson et al., 1993; Roberts et al., 1995; Xie et al., 1995; Green et al., 1998).

However, owing to mutations around the active site that would likely interfere with the catalytic mechanism, bovine and ovine PAG-I are probably not able to act as proteolytic enzymes. This feature cannot be discussed completely because most PAG molecules are yet to be discovered and characterised (Table 1).

Table 1

PAGs and PSPB identified so far in placenta or in serum

\begin{tabular}{|c|c|c|c|c|}
\hline \multirow[t]{2}{*}{ Family } & \multirow[t]{2}{*}{ Species } & \multicolumn{2}{|c|}{$\begin{array}{c}\text { Presence of } \\
\text { pregnancy proteins }\end{array}$} & \multirow[t]{2}{*}{ Authors } \\
\hline & & PAG & PSPB & \\
\hline \multirow[t]{3}{*}{ Ruminant } & Bovine (Bos taurus) & + & + & $\begin{array}{l}\text { Butler et al. 1982; Zoli et } \\
\text { al., 1991; Xie et al., } 1991\end{array}$ \\
\hline & Ovine (Ovis aries) & + & + & $\begin{array}{l}\text { Zoli et al., 1995; Willard et } \\
\text { al., 1995; Xie et al., } 1991\end{array}$ \\
\hline & Caprine (Capra hircus) & + & + & $\begin{array}{l}\text { Humblot et al., } 1990 \text { and } \\
\text { 1992; Garbayo et al., } 1998\end{array}$ \\
\hline \multirow[t]{6}{*}{ Cervid } & $\begin{array}{l}\text { Rocky mountain elk (Cervus } \\
\text { elaphus nelsoni) }\end{array}$ & & + & Willard et al., 1994 \\
\hline & Fallow deer (Dama dama) & & + & Willard et al., 1994 \\
\hline & $\begin{array}{l}\text { Mule deer (Odocoileus hemi- } \\
\text { onus) }\end{array}$ & & + & Wood et al., 1986 \\
\hline & $\begin{array}{l}\text { White-tailed deer (Odocoileus } \\
\text { virginianus) }\end{array}$ & + & & $\begin{array}{l}\text { Wood et al., 1986; Osborn } \\
\text { et al., } 1996\end{array}$ \\
\hline & Japanese deer (Cervus nippon) & & + & Willard et al., 1994 \\
\hline & $\begin{array}{l}\text { Wood bison (Bison bison ath- } \\
\text { bascae) }\end{array}$ & & + & Haigh et al., 1991 \\
\hline \multirow[t]{2}{*}{ Equine } & Horse (Equus caballus) & + & & Green et al., 1994 \\
\hline & Zebra (Equus zebra) & + & & Gan et al., 1997 \\
\hline Feline & Cat (Felis domestica) & + & & Gan et al., 1997 \\
\hline Porcine & Pig (Sus scrofa domestica) & + & & Szafranska et al., 1995 \\
\hline
\end{tabular}


Although initially it was believed that there was only a single PAG molecule, it has become increasingly clear that there are possibly more than one hundred PAG genes in ruminants and that most of these genes are expressed. Genomic Southern Blot analysis performed with extron-specific probes under stringent conditions provided the initial hint that the PAG gene family was a large and complex one (Green et al., 1998).

\section{PAG assays in various species of ruminants}

In relation to experimental reproductive physiology and veterinary practice, assays on PAG molecules close to PAG-I have been developed in different species.

\section{1. Cattle}

In 1992, Zoli et al. published the profile for PAG-I-67 during bovine pregnancy and recommended to use the RIA test for early pregnancy diagnosis. As a common rule, PAG-I-67 appears in the peripheral blood of the mother (or embryo recipient) around day 30 after fertilisation, with a great variability between females. Some cows presented very low levels even at Day 40, when their pregnancies were already confirmed by ultrasonography (Szenci et al., 1998a). After Day 40, its plasma levels progressively increase to reach maximum values (1 to $5 \mu \mathrm{g} / \mathrm{ml}$ ) around parturition (Zoli et al., 1992). The relatively long time needed for bPSPB or bPAG-I to be cleared from maternal circulation can be explained by the very high concentrations present in blood at parturition as well as by a long specific half-life of these proteins (Ruder and Sasser, 1986; Humblot et al., 1988b; Zoli et al., 1992; Kirakofe et al., 1993). Higher concentrations were observed in maternal serum than in fetal serum, suggesting that the glycoprotein synthesized by the fetal placenta is secreted mainly into the maternal circulation. Investigations made in the peripartal period clearly demonstrated the positive influence of both maternal environment and fetus genotype (sex and family) on peripheral concentrations of bPAG. The experiments of inter-species fertilisations confirmed this hypothesis because the expression of antigens by trophoblast cells are recognized as foreign bodies by the maternal immune system. In fact, the trophoblasts of crossbred fetuses express more similar antigens to the mother than fetuses unrelated to the breed of the recipient. So, concentrations of bPAG will be found to be more elevated in intra-species crossbreds than in inter-species ones (Fernández-Arias et al., 1999).

After IVF or cloning, the follow-up of PAG in plasma samples collected weekly was suitable for monitoring embryonic or fetal deaths (Ectors et al., 1996). In the veterinary practice, radioimmunoassays (RIAs) of PAG and/or PSPB in plasma samples are helpful to confirm pregnancy diagnoses established 
by rectal palpation or ultrasonography (Szenci et al., 1998b). Moreover, the follow-up of both bPAG and PSPB during pregnancy permits to keep track of the viability of the fetoplacental unit. However, due to large variations in bPAG/ PSPB concentrations of the maternal blood, only the marked decrease (or disappearance) of the serum concentrations of these proteins can be an unambiguous predictive sign of embryonic or fetal death (Szenci et al., 1999). At the same time, abnormal elevations in their concentrations reveal inter-species breeding or abnormal amount of trophoblastic tissues as observed in hydatiform molar pregnancy (Ectors et al., 1996).

Ectors et al. (1996) showed that in nuclear transfer programs, even if the majority of calves are of normal size, some of them can present morphological abnormalities among which one, placental hypertrophy with an increase in the number and diameter of cotyledons, is responsible for hyper-secretions of bPAG. Data obtained from this associated research ('cloned embryos and bPAG pregnancy follow-up') may permit to suggest the existence of a complex syndrome associating large calves at birth, trophoblastic hypertrophy, and abnormal profiles of bPAG.

\section{2. Sheep}

In sheep, profiles of PAGs were also determined and appeared quite different than those obtained in cattle. After a first period of high concentration around Day 60, the concentrations decrease until Day 90 and increase again to remain elevated and stable until parturition (Ranilla et al., 1994). The postpartum decrease in plasma concentrations in this species is more rapid than that described in bovine profiles (Zoli et al., 1992; Ranilla et al., 1994).

As the placenta rescues the corpora lutea for progesterone synthesis around Day 50, the pseudopregnancy syndrome was rarely observed in this species. Indeed, after embryonic or fetal death occurring between Days 25 and 50 of pregnancy, the interruption of gestation or pseudopregnancy and 'opening' of the cervix occur around Day 50 to 60 when the corpora lutea decrease their progesterone production and secretion and are not relayed by the placenta.

\section{3. Goats}

In goats, Sousa et al. (1998) simultaneously examined the profiles of P4 and PAG in two native breeds (Moscoto and Canindé) from Northeast Brazil. Goats carrying two fetuses had higher PAG concentrations during pregnancy than those carrying a single fetus. However, significant differences were only found in weeks 15, 17 and 19, respectively.

Based on the physiology of the pregnancy in the goat, caprine pregnancy is dependent on corpus luteum until the end of pregnancy. Therefore, it is surprising that progesterone synthesis was decreased during some weeks in mid- 
pregnancy and re-established by the end of pregnancy. The persistence of pregnancy even with very low levels of progesterone might be explained by the rapid rate of the metabolism of progesterone into $5-\beta$-pregnane-3 $\alpha-20 \alpha$-diol which is responsible for the main placental progestative activity during goat pregnancy. This molecule has been reported to occur in extracts of placenta cultured in vitro. Unfortunately, it does not cross-react in RIA of progesterone (Sousa et al., 1998). This fact has to be distinguished from the 'pseudopregnancy syndrome' found in this species (up to $10 \%$ in some breeds) and is characterised by high remaining progesterone concentrations in non-pregnant females that have (or have not) been fertilised. In this species, the absence of rescue by the placental unit for secretion of progesterone explains the possibility for the corpus luteum to work 'on its own' and continue its secretion of P4 for a period equal or superior to normal pregnancy. In these cases, progesterone concentrations are higher than $1 \mathrm{ng} / \mathrm{ml}$ (i.e. active CL) while PAG concentrations remain at basal levels (Sousa et al., 1998; Zarrouk et al., 1998). The combination of ultrasonography with plasmatic assays of PAG/PSPB will be of interest in these cases. The treatment of these pathologies relies on the administration of prostaglandins.

\section{Perspectives}

At present we are looking for new PAG forms in order to improve the accuracy of pregnancy diagnoses in the cow (Szenci et al., 1998b). Nowadays the PAG-I-67 RIA system (classical RIA) is used for pregnancy diagnosis in the practice. In this RIA test, an antiserum against the $67 \mathrm{kDa}$ PAG purified by Zoli et al. (1991) is used. Pure 67kDa bovine PAG is purified once a year according to the method described by Zoli et al. (1991).

After purifying mid-pregnant goat placenta, three new forms of PAG have been characterised recently: PAG-55, PAG-59 and PAG-62 (Garbayo et al., 1998). Two purified preparations are now available: a mixture of 55 and $59 \mathrm{kDa}$ PAG and of 55 and $62 \mathrm{kDa}$ PAG. Antisera were raised against these substances in rabbits. The dilution titre of the antiserum against the 55 and $59 \mathrm{kDa} P A G$ is 1:150,000. At present we use the $55+59 \mathrm{kDa}$ PAG RIA in comparison with the classical system of $67 \mathrm{kDa}$ PAG in order to improve the accuracy of the RIA test. According to our preliminary results (Perényi, 1998), a high correlation $(\mathrm{r}=0.922)$ was found between the two assays. The PAG $55+59$ system could be useful to set up pregnancy diagnosis in doubtful cases (close to the threshold value) obtained by the classical RIA method. It could also be possible that pregnancy diagnosis based on the PAG $55+59$ RIA system would be more accurate than the PAG 67 RIA method. This hypothesis has to be verified by further investigations using a large 
number of pregnant and non-pregnant plasma samples that would permit us to define the threshold value for the application of the PAG $55+59$ RIA.

In conclusion, after a few years of collaborative efforts aimed at evaluating the value of PAG determination in physiological and pathological situations, we suggest multiple approaches combining clinical (ultrasound) examinations in conjunction with serological determination of progesterone (P4), different PAGs, oestrone sulphate and placental lactogen in order to gain a better understanding of the physiology and pathology of placental function. Such longitudinal studies are expected to bring abundant information on the pathogenesis of trophoblastic distresses leading to embryonic or fetal death.

\section{Acknowledgements}

This review is part of a study supported by the following grants. The investigations realised in Belgium were funded by FNRS and IRSIA grants to J. F. Beckers; J. M. Garbayo is supported by a grant from the Spanish Ministry of Agriculture, Fisheries and Food. A. Zarrouk was supported by a grant from the Tunisian Ministry of Education. The Hungarian part of the study was supported by the Hungarian Scientific Research Fund (OTKA), grant no. OTKA T016901.

\section{References}

Aschheim, S. and Zondek, B. (1928): Die Schwangershaftsdiagnose aus dem Harn durch Nachweis des Hypophysenvorderlappenhormons. Klin. Wschr. 7, 1404-1411.

Atkinson, Y. H., Gogolin-Ewens, K. J., Hounsel, E. F., Davies, M. J., Brandon, M. R. and Seamark, R. F. (1993): Characterization of placentation-specific binucleate cell glycoproteins possessing a novel carbohydrate. J. Biol. Chem. 268, 26679-26685.

Beckers, J. F., Zarrouk, A., Batalha, E. S., Garbayo, J. M., Mester, L. and Szenci, O. (1998): Endocrinology of pregnancy: Chorionic Somatomammotropins and Pregnancy-associated Glycoproteins: Review. Acta Vet. Hung. 46, 175-189.

Bohn, H. (1979): Isolation and characterization of placental proteins with special reference to pregnancy-specific $\alpha-1$-glycoprotein and other proteins specific to the placenta. In: Klopper, A. and Chard, T. (eds) Placental Proteins. Springer-Verlag, Berlin. pp. 71-88.

Butler, J. E., Hamilton, W. C., Sasser, R. G., Ruder, C. A., Hass, G. M. and Williams, R. J. (1982): Detection and partial characterization of two bovine pregnancy-specific proteins. Biol. Reprod. 26, 925-933.

Ectors, F. J., Drion, P. V., Delval, A., Smith, L. C., Sulon, J., Zaaier, D., Szenci, O., Remy, B., Beckers, J. F. and Ectors, F. (1996): Interests of pregnancy follow-up in cows after embryo transfer: special focusing on IVP \& NT. $12^{\grave{e}}$ Colloque Association Européenne de Transfer Embryonnaire, Lyon. pp. 95-103.

Fernández-Arias, A., Alabart, J. L., Folch, J. and Beckers, J. F. (1999): Interspecies pregnancy of Spanish ibex (Capra pyrenaica) fetus in domestic goat (Capra hircus) recipients induces abnormally high plasmatic levels of pregnancy-associated glycoprotein. Theriogenology (submitted). 
Gan, X., Xie, S., Green, J. and Roberts, R. M. (1997): Identification of transcripts for pregnancy associated glycoprotein (PAG) in Carnivora and Perissodactyla. Biol. Reprod. 56, Abstract 431.

Garbayo, J. M., Remy, B., Alabart, J. L., Folch, J., Wattiez, R., Falmagne, P. and Beckers, J. F. (1998): Isolation and partial characterization of a Pregnancy-Associated Glycoprotein family from the goat placenta. Biol. Reprod. 58, 109-115.

Green, J., Xie, S., Newman, A., Szafranska, B., Roberts, R. M., Baker, C. B. and McDowell, K. (1994): Pregnancy associated glycoproteins of the horse. Biol. Reprod. 50, (Suppl. 1): Abstract 152.

Green, J. A., Xie, S. and Roberts, R. M. (1998): Pepsin-related molecules secreted by trophoblast. Rev. Reprod. 3, 62-69.

Haigh, J. C., Gates, C., Ruder, A. and Sasser, R. G. (1991): Diagnosis of pregnancy in wood bison using a bovine assay for pregnancy-specific protein B. Theriogenology 36, 749-754.

Humblot, P., Camous, S., Martal, J., Charlery, J., Jeanguyot, N., Thibier, M. and Sasser, R. G. (1988a): Diagnosis of pregnancy by radioimmunoassay of a pregnancy-specific protein in the plasma of dairy cows. Theriogenology 30, 257-268.

Humblot, P., Camous, S., Martal, J., Charlery, J., Jeanguyot, N., Thibier, M. and Sasser, R. G. (1988b): Pregnancy specific protein B, progesterone concentrations and embryonic mortality during early pregnancy in dairy cows. J. Reprod. Fert. 83, 215-223.

Humblot, P., Courtin, H., Jeanguyot, N., Thibier, M. and Sasser, R. G. (1992): Pregnancy specific protein $\mathrm{B}$ and oestrone sulfate concentrations during pregnancy and embryonic mortality in dairy goats. $12^{\text {th }}$ International Congress on Animal Reproduction. The Hague, Netherlands. pp. 2.

Humblot, P., de Montigny, G., Jeanguyot, N., Tetedoie, F., Payen, B., Thibier, M. and Sasser, R. G. (1990): Pregnancy-specific protein B and progesterone concentrations in French alpine goats throughout gestation. J. Reprod. Fert. 89, 205-212.

Kirakofe, G. H., Wright, J. M., Schalles, R. R., Ruder, C. A., Paris, S. and Sasser, R. G. (1993): Pregnancy-specific protein B in serum of postpartum beef cows. J. Anim. Sci. 71, 2199-2205.

Laster, D. B. (1977): A pregnancy-specific protein in the bovine uterus. Biol. Reprod. 16, 682-690.

Lynch, K. A., Alexander, R. M. and Sasser, R. G. (1992): The cloning and expression of the bovine pregnancy specific protein B (bPSPB) gene. Biol. Reprod. 46, (Suppl. 1): Abstract 73.

Osborn, D. A., Beckers, J. F., Sulon, J., Gasset, J. W., Muller, L. I., Murphy, B. P., Miller, K. V. and Marchinton, R. L. (1996): Use of glycoprotein assays for pregnancy diagnosis in white-tailed deer. J. Wildl. Manage. 60, 388-393.

Perényi, Zs. (1998): Comparison of different RIA systems for PAG determination. Personal communication.

Ranilla, M. J., Sulon, J., Carro, M. D., Mantcon, A. R. and Beckers, J. E. (1994): Plasmatic profiles of pregnancy-associated glycoprotein and progesterone levels during gestation in Churra and Merino sheep. Theriogenology 42, 537-545.

Roberts, R. M., Xie, S., Nagel, R. J., Low, B., Green, J. and Beckers, J. F. (1995): Glycoproteins of the aspartyl proteinase gene family secreted by the developing placenta. In: Takahashi, K. (ed.) Aspartic Proteinases: Structure, Function, Biology, and Biomedical Implications. Plenum Press, Tokyo. pp. 231-240.

Ruder, C. A. and Sasser, R. G. (1986): Source of bovine pregnancy specific protein B (bPSPB) during the postpartum period and estimation of half-life of bPSPB. J. Anim. Sci. 69, (Suppl.) Abstract 660.

Sasser, R. G., Crock, J. and Ruder, C. A. (1989): Characteristics of pregnancy-specific protein B in cattle. J. Reprod. Fert. 37, (Suppl.) 109-113.

Sasser, R. G., Ruder, C. A., Ivani, K. A., Butler, J. E. and Hamilton, W. C. (1986): Detection of pregnancy by radioimmunoassay of a novel pregnancy-specific protein in serum of cows and a profile of serum concentrations during gestation. Biol. Reprod. 35, 936-942.

Sciarra, J. J., Kaplan, S. L. and Grumbach, M. M. (1963): Localization of anti-human growth hormone serum within the human placenta: evidence for a human chorionic growth hormone-prolactin. Nature 199, 1005-1006. 
Sousa, N. N., Garbayo, J., Figueiredo, J. R., Sulon, J., Goncalves, P. B. D. and Beckers, J. F. (1998): Pregnancy-associated glycoprotein and progesterone profiles during pregnancy and post partum in native goats from the north-east of Brazil. Small Ruminant Research 32, $137-147$.

Szafranska, B., Xie, S., Green, J. and Roberts, R. M. (1995): Porcine pregnancy-associated glycoproteins: new member of the aspartic proteinase gene family expressed in trophectoderm. Biol. Reprod. 53, 21-28.

Szenci, O., Beckers, J. F., Humblot, P., Sulon, J., Sasser, R. G., Taverne, M. A. M., Varga, J., Baltusen, R. and Schekk, Gy. (1998b): Comparison of ultrasonography, bovine pregnancyspecific protein $\mathrm{B}$, and bovine pregnancy-associated glycoprotein 1 tests for pregnancy detection in dairy cows. Theriogenology $\mathbf{5 0}, 77-88$.

Szenci, O., Humblot, P., Beckers, J. F., Sasser, R. G., Sulon, J., Baltusen, R., Varga, J., Bajcsy Á. Cs. and Taverne, M. A. M. (1999): Plasma profiles of progesterone and conceptus proteins in cows with spontaneous embryonic/fetal mortality as diagnosed by ultrasonography. The Vet. J. (in press).

Szenci, O., Taverne, M. A. M., Beckers, J. F., Sulon, J., Varga, J., Börzsönyi, L., Hanzen, Ch. and Schekk, Gy. (1998a): Evaluation of false ultrasonographic diagnoses in cows by measuring plasma levels of bovine pregnancy-associated glycoprotein 1. Vet Rec. 142, 304-306.

Willard, S. T., Sasser, R. G., Gillespie, J. C., Jaques, J. T., Welsh, T. H. Jr. and Randel, R. D. (1994): Methods for pregnancy determination and the effects of body condition on pregnancy status in Rocky Mountain elk (Cervus elaphus nelsoni). Theriogenology 42, 1095-1102.

Willard, J. M., White, D. R., Wesson, C. A. R., Stellflug, J. and Sasser, R. G. (1995): Detection of fetal twins in sheep using a radioimmunoassay for pregnancy-specific protein B. J. Anim. Sci. 73, 960-966.

Wood, A. K., Short, R. E., Darling, A. E., Dusek, G. L., Sasser, R. G. and Ruder, C. A. (1986): Serum assays for detecting pregnancy in mule and white-tailed deer. J. Wildl. Manage. 50, 684-687.

Xie, S., Green, J., Bao, B., Beckers, J. F., Valdez, K. E., Hakami, L. and Roberts, R. M. (1997): Multiple pregnancy-associated glycoproteins are secreted by day 100 ovine placental tissue. Biol. Reprod. 57, 1384-1393.

Xie, S., Green, J., Beckers, J. F. and Roberts, R. M. (1995): The gene encoding bovine pregnancy-associated glycoprotein-1, an inactive member of the aspartic proteinase family. Gene 159, 193-197.

Xie, S., Low, R. C., Nagel, R. J., Kramer, K. K., Anthony, R. V., Zoli, A. P., Beckers, J. F. and Roberts, R. M. (1991): Identification of the major pregnancy-specific antigens of cattle and sheep as inactive members of the aspartic proteinase family. Proc. Natl. Acad. Sci. USA 88, 10247-10251.

Zarrouk, A., Remy, B., Sulon, J., Drion, P. V., Desbuleux, H. and Beckers, J. F. (1998): Endocrinology of pregnancy in ruminants: the placental proteins (in French). Ann. Méd. Vét. 142, $171-184$.

Zoli, A. P., Beckers, J. F. and Ectors, F. (1995): Isolation and partial characterization of a pregnancy associated glycoprotein in sheep (in French). Ann. Méd. Vét. 139, 177-184.

Zoli, A. P., Beckers, J. F., Wouters-Ballman, P., Closset, J., Falmagne, P. and Ectors, F. (1991): Purification and characterization of a bovine pregnancy-associated glycoprotein. Biol. Reprod. 45, 1-10.

Zoli, A. P., Guilbault, L. A., Delahaut, P., Benitez-Ortiz, W. and Beckers, J. F. (1992): Radioimmunoassay of a bovine pregnancy-associated glycoprotein in serum: its application in pregnancy diagnosis. Biol. Reprod. 46, 83-92. 